\title{
İnsan Haklarının ve Temel Özgürlüklerin İhlaline Yönelik Sınıf Öğretmeni Adaylarının Farkındalık Durumlarının İncelenmesi
}

\author{
Erdem HAREKET \\ Kırıkkale Üniversitesi Eğitim Fakültesi \\ erdemhareket@gmail.com \\ ORCID ID: 0000-0003-3903-7057.
}

\begin{tabular}{lrr} 
Araştırma Makalesi & DOI: $10.31592 /$ aeusbed.907254 \\
\hline Geliş Tarihi: 31.03 .2021 & Revize Tarihi: 14.07 .2021 & Kabul Tarihi: 08.07.2021
\end{tabular}

\section{Atıf Bilgisi}

Hareket, E. (2021). İnsan haklarının ve temel özgürlüklerin ihlaline yönelik sınıf öğretmeni adaylarının farkındalık durumlarının incelenmesi. Ahi Evran Üniversitesi Sosyal Bilimler Enstitüsü Dergisi, 7(2), 602-619.

\section{ÖZ}

Bu araştırmada Türkiye'nin çeşitli üniversitelerinde öğrenim görmekte olan sınıf öğretmeni adaylarının, insan hak ve özgürlükleri noktasında ulusal ve uluslararası ölçekteki ihlallere, bunların nedenlerine ve bu ihlallerin önlenmesi noktasındaki önerilerine yönelik farkındalık durumlarının belirlenmesi amaçlanmıştır. Araştırmaya, ölçüt örneklem yöntemi ile belirlenmiş 702 öğretmen adayı katılmıştır. Nitel araştırma yaklaşımına uygun olarak tasarlanan araştırmada veriler, katılımcılar tarafindan oluşturulmuş olan yazılı dokümanlar ile elde edilmiştir. Edinilen nitel veriler içerik analizi ve betimsel analiz tekniği ile analiz edilmiştir. Araştırma bulguları incelendiğinde katılımcıların, küresel çerçevede en çok yaşam hakkı, eğitim hakkı, çocuk hakları, ayrımcılıktan korunma ve vücut bütünlüğü ve dokunulmazlığı hakkının ihlal edildiğini, ülkemiz özelinde ise küresel çerçevede belirtilen bu ihlal alanlarına ilaveten yoğun olarak cinsel dokunulmazlık hakkının, düşünce ve ifade hürriyeti hakkının, şiddetten korunma hakkının, adil yargılanma ve savunma, özgürlük ve güvenlik, siyasal haklar, eșitlik ve basın hürriyeti haklarının ihlal edildiği belirtilmiștir. $\mathrm{Bu}$ ihlallerin gerekçelerine yönelik olarak ise ekonomik sebeplerin, geleneksel anlayışların, örf ve adetlerin, politik çıkar çatışmalarının, kamu yönetimindeki antidemokratik uygulamaların, plansız nüfus politikalarının, eğitim sistemlerindeki eksikliklerin ve yanlış politikaların işaret edildiği sonucuna ulaşılmıştır. Araştırmada ayrıca ülkemizde yaşanan insan hak ve özgürlük ihlalleri konusunda katılımcılar arasında önemli düzeyde bir görüş birliğinin mevcut olduğu sonucuna da ulaşılmıştır. Araştırma sonuçları doğrultusunda, öğretmen adaylarının küresel ve yerel çerçevede mevcut olan insan hak ve özgürlük ihlallerine ilişkin belirli bir farkındalığa sahip oldukları, bununla birlikte insan hakları ve özgürlüklerine ilişkin konularda eğitim ihtiyaçlarının varlığına yönelik değerlendirmeler ortaya koydukları görülmüştür.

Anahtar Kelimeler: İnsan hakları, özgürlükler, hak ihlalleri, öğretmen adayları, hak ihlaline ilişkin farkındalık.

\section{Primary School Teacher Candidates' Awareness Situation Regarding Violations of Human Rights and Fundamental Freedoms}

\begin{abstract}
In this research, it is aimed to determine the awareness of primary school teacher candidates related to the human rights violations in context of national and international, their cause dynamics and their suggestions for preventing these violations. 702 teacher candidates who were determined by criterion sampling method participated in the research. The data of the research which was designed in accordance with the qualitative research approach, were obtained with written documents created by the participants. The qualitative data obtained were analyzed using the content analysis technique. When the findings of the research are examined it seems to be expressed by participants that some rights are violated in a global context such as the right to life, the right to education, children's rights, protection from discrimination and bodily integrity and immunity globally. In Turkey, it was stated that in addition to these areas of violation specified in the global framework, the right to sexual immunity, the right to freedom of thought and expression, the right to be protected from violence, fair trial and defense, freedom and security, political rights, equality and freedom of the press were violated. As for the reasons for these violations, it was concluded that economic reasons, traditional understandings, customs and traditions, conflicts of political interest, anti-democratic practices in public administration, unplanned population policies, deficiencies in education systems and wrong policies were pointed out. In line with the results of the research, it has been observed that the primary school teacher candidates have a significant level of awareness of the violations of human rights and freedoms existing in the global and local framework, on the other hand they put forward evaluations regarding the existence of training needs in these issues.
\end{abstract}

Keywords: Human rights, freedoms, violations of rights, primary school teacher candidates, awareness of human rights violations. 


\section{Giriş}

Hak kavramının, toplumsal bir varlık olarak insanın henüz daha dünyaya gelmeden sahip olduğu, toplumsal bir örgüt olarak da otoriteler tarafından korunma yükümlülüğünü işaret eden ve hukuk normlarınca da güvence altına alınmış olan bir kavram olarak tarif edilmesi mümkündür. Hareket (2020), bütün iklimlerde insanın anne rahminde varoluşu ile birlikte sahip olduğu birtakım hakların, hâlihazırda ülkeleri yöneten otoriteler tarafından korunma ve geliştirilme yükümlülügü doğurmakta olduğunu ifade etmektedir. Nitekim bu husus, gerek birey-birey gerekse birey-devlet arasındaki ilişkilerin insan hak ve özgürlükleri çerçevesinde yürütülmesinde bir gerekliliktir. Benzer şekilde Jennigs (2006) sahip olunan hakların, insanların onurlu bir hayat sürmeleri maksadıyla ihtiyaç duyulan koşulları ana hatlarıyla çizen standartlar olduğunu ve bu standartların hükümetler, kurumlar, topluluklar ve şahıslar tarafından korunmaya ve desteklenmeye değer olduğunu ifade etmektedir. $\mathrm{Bu}$ noktada insan hak ve özgürlüklerine yönelik ortaya konacak geliştirici ve ilerici yaklaşımların, toplumsal hayatın düzeni, kamu refahının tesisi, devlete bağlılık, milli ve yerel unsurları benimseme ve demokratik değerlerin bireyler arasında yerleşik hale getirilmesi hususlarına temel dayanak oluşturacağına dikkat çekmek isteriz.

Nitekim küresel ve yerel ölçekte hızlı ve çeşitli değişim süreçleri yaşanıyor olsa da, insan hakları kavramının halen demokratik toplumların vazgeçilmez kavramlarından bir tanesi olduğu ve bu hususa ilişkin eğitim, hukuk ve politika çalışmalarının hız kesmeden sürdürüldüğü bir gerçektir. $\mathrm{Bu}$ durumun temel gerekçelerinden bir tanesi, değişen yaşam koşullarına paralel olarak insanın içinde yaşadığı toplumsal hayata uyumunun tüm değişimlerin aksine sabit bir gerekliliği ifade etmesidir. Dolayısıyla, insanların temel hak ve özgürlüklerine ilişkin gerçekleştirilecek çalışmaların ne önem derecesinin ne de içerik yönünün azalan/negatif yönde bir trende girmiş olduğunu söylememiz mümkün değildir. Bu bağlamda, toplumsal dokunun şekillenmesinde, insan hak ve hürriyetlerinin, demokratik ilkelerin ve değerlerin hâkim kılındığ 1 bir anlayışın toplumu ilgilendiren tüm alanlarda yerleşik hale getirilmesinde hiç kuşkusuz eğitimin önemli bir misyona sahip olduğunu belirtmek gerekmektedir. Bu husus Avrupa İnsan Hakları Evrensel Sözleşmesi'nin 26. maddesinde; “Öğretim insan şahsiyetinin tam gelişmesini ve insan haklariyla ana hürriyetlerine saygının kuvvetlenmesini hedef almalıdır. Öğretim bütün milletler, ırk ve din grupları arasında anlayış, hoşgörü ve dostluğu teşvik etmeli ve Birleşmiş Milletler 'in barışın idamesi yolundaki çalışmalarını gelişstirmelidir." ibaresi ile beyan edilmiştir. Bu bağlamda insan hakları hukukunun normları arasında yer alan uluslararası sözleşmelerde de eğitimin, temel hak ve özgürlükleri güçlendirmede, geliştirmede ve insan hakları kültürünün toplumsal yaşamda hâkim kılınmasında önemli bir rolü olduğu kabul edilmektedir. Bugünün ve gelecek nesillerin sahip oldukları/olacakları temel hak ve özgürlüklerin güvence altına alınmasındaki birincil yol kuşkusuz eğitim ve öğretimdir (Jennings, 2006).

Çocuk Hakları Evrensel Sözleşmesi'ne bakıldığında da çocuklara ve yetişkinlere yönelik hak eğitimlerinin, taraf ülkeler açısından bir yükümlülük olarak beyan edildiği görülmektedir. Bu noktada eğitim unsurlarının insan hak ve özgürlüklerine ilişkin belirli bir duyarlılık düzeyine, içeriğine ve donanımına sahip olması gerektiğini söylemek mümkündür. Kucaklayıcı, çoğulcu ve farklılıklara değer veren, toplumsal ve siyasal yaşantıda etkin katılım sağlayabilen, demokratik değerlerin benimsendiği bir yapıya ulaşılmasını amaçlayan bir eğitim, temel hak ve özgürlüklerinin farkında olan ve bunları içselleştiren, diğer bireylerin de haklarını en az kendi hakları kadar kutsal sayan kişilerin varlığı ile mümkündür (Akyeşilmen, 2014). Benzer şekilde Hareket ve Yel (2021) tarafından, insan haklarının korunduğu ve gelişiminin desteklendiği demokratik bir hukuk devletinde, bireylerin haklarının bilincinde olmalarının, başkalarının haklarını da gözeten tutumlar sergilemelerinin ve bununla birlikte bu konuda yeterli farkındalığa sahip olmalarının bekleneceğine dikkat çekilmiştir. Söz konusu hususlardan yola çıkılarak, bir toplumun bireylerinin, insan hak ve özgürlüklerinin gerçekte ne olduğu, ne anlama geldiği konusunda eğitilmesi gerektiği ve şahsi olarak insan haklarının içselleştirilmesi gerektiği ifade edilebilir (Emmert ve Eur, 2011).

Gelinen noktada, toplumsal yaşamın içerisinden bir konu alanı olarak karşımıza çıkan insan hak ve özgürlükleri, ulusal ve uluslararası hukukun yanı sıra toplum inşasının da temel argümanlarından olan eğitimin ve eğitim unsurlarının temel konuları arasında bulunmaktadır. Hareket 
(2019), toplumsal yaşantılarda var olan unsurların bazı güçlü kaygıları, belirsizlikleri ve kuşkuları taşımakta olduğunu ve bu unsurlar arasında, eğitim ve ona bütünleşik faktörlerin en önde yer aldığını bu bağlamda eğitimin, toplumsal yaşamın idaresi ve rehberlik edilmesinde dinamik bir araç ve bir düşüncenin uygulama alanı olduğunu ifade etmektedir. Eğitimin vurgulandığı şekli ile bir uygulama alanı olduğu kabul edildiğinde, bazı kavramları içselleştirmenin en etkili yolunun eğitim olduğu söylenebilir. İnsan haklarının bireylerde kalıcı olması gerektiğinden, okul, bireyin insan haklarını anlamasında ve onların bu haklara saygı duymasını sağlamada, tutum ve davranışlarını şekillendirmede önemli bir misyona sahiptir (Varl1, 2020).

Şüphesiz bu tespit, eğitim süreçlerinin temel unsurlarından olan eğitimcilerin ve adaylarının insan hakları konusunda yeterli bilgi ve duyarlılık düzeyine ulaşmış olması gerekliliğini gündeme getirmektedir. Çünkü insan haklarına ilişkin farkındalık kazandırma süreçleri, öğretmenlerin doğrudan bu konulardaki anlatımları ile değil çocukları bu konudaki yargılarını ve algılarını ne yönde dönüştürebildiği ile ilgilidir (Adami, 2014). Ancak bu gerekliliğin göz önünde bulundurulduğu, eğitimcilerin ve eğitimci adaylarının insan hakları, çocuk hakları ve hak eğitimi konu alanlarını içeren süreçler ile buluşabildiği formal ve informal ortamlar ne yazık ki son derece sinırlıdır. Bu tespiti, lisans öğretim programlarına, hizmet içi eğitim planlamalarına ve bu konuda farklı kurum kuruluşlarca desteklenerek gerçekleştirilen farkındalık oluşturucu etkinliklerin (seminer, konferans, proje vb.) sıklıklarına ilişkin veriler ile desteklemek mümkündür. Bu noktada, insan haklarına duyarlı bir eğitim ortamının ve toplumsal dokunun oluşturulabilmesinde, eğitimcilerin ve adaylarının konuya ilişkin belirli düzeyde bilince sahip olmaları, bu konuda gerekli eğitim ve öğretim faaliyetlerine aktif biçimde katılmış olmaları ve insan hakları değerini içselleştirmiş olmaları gerekmektedir. Söz konusu olan bu bilinç düzeyinin kapsamı içerisinde insan hakları ve özgürlükleri mevzuatı, bunların ulusal ve uluslararası ölçekteki ihlal alanları, hukuki koruma mekanizmaları ve insan hakları eğitimi gibi konular yer almaktadır. "Okullarda İnsan Haklarının Öğretilmesi ve Öğrenilmesi” başlıklı Avrupa Konseyi Tavsiyesi'nde (1985), insan hakları eğitiminin beceriler, bilgi ve duygular olmak üzere üç ana boyutunun bulunduğu, bununla birlikte duyuşsal boyutun, olgular ve pedagoji kadar insan hakları alanında başarılı öğretmen eğitimi için kritik öneme sahip olduğu belirtilmiştir. Bu bağlamda insan haklarına duyarlı bir toplumsal yapının inşasında eğitimcilerin ilgili konuda önemli bir misyona sahip oldukları ve hizmet öncesi süreçten itibaren yine bu konuda bilinçli ve duyarlı olmak gibi bir sorumluluğa da sahip olduklarını belirtmek isteriz. Şüphesiz belirtilen sorumluluk, öğretmen yetiştirme sisteminin yürütücüleri açısından daha da görünür bir boyuttadır. Robinson, Phillips ve Quennerstedt (2018) eğitimcilerin, öğrencilere insan hakları ilkelerinin doğasında var olan değerleri öğretme sorumluluğu taşıdığını ifade etmişlerdir. Benzer şekilde Dewey (1990), sosyal yaşama ilk adımların eğitim kurumlarında atılacağını, demokratik değerlere dayalı bir eğitim aracılığıyla da bireyin içinde yaşadığı toplumu iyileştirebileceğini/geliştirebileceğini ve söz konusu olan bu toplumda herkesin eşit haklara sahip ve haklara duyarlı olduğu bir ortamın bu sayede oluşturabileceğini öne sürmüştür.

$\mathrm{Bu}$ görüşler doğrultusunda eğitimcilere, bilhassa da sınıf öğretmenleri ve adaylarına oldukça önemli bir rol düşmektedir. Çiydem (2014), insan hakları ve demokrasi konularına ilişkin eğitim faaliyetlerindeki en etkili kişilerin ilk etapta sınıf öğretmenleri olduğunu belirtmiştir. Nitekim Struthers (2016), öğrencilerin erken yaşlardan itibaren ilgili değer ve kavramlarla karşılaşmalarının sağlanmasıyla, insan haklarına yönelik olumsuz tutumların başlamadan önüne geçilmesinin mümkün olabileceğine dikkat çekmiştir. Buna paralel olarak Isenström (2021), insan hak ve özgürlükleri konusunda bilinçli eğitimciler tarafindan çocuklara insan haklarının öğretilmesinin, uluslararası insan haklarını güçlendirmede atılabilecek önemli adımlardan olduğunu belirtmiştir. Sözü edilen bu önemli adımlardan bir tanesini atacak pozisyonda yer alan başta sınıf öğretmenlerinin, başarılı bir insan hakları eğitimcisi olabilmelerinin, ilk olarak insan hak ve özgürlüklerine ilişkin konularda farkındalık kazanmış bir öğretmen adayı olmaları koşuluna bağlı olduğu düşünülmektedir. Bu tespiti destekler nitelikte, insan hak ve özgürlüklerine ilişkin konularda yeterli farkındalı̆̆a ve bilgiye sahip olmayan eğitimcilerin bu konuda düşük özgüven sergiledikleri, insan hakları terminolojisinde eksiklik hissettikleri ve insan hakları çerçevesine uygun ve bunu güçlendirici ortamlar oluşturmada zorluk yaşadıkları ifade edilmektedir (Cassidy, Brunner ve Webster, 2014; Covell, Howe ve McNeil, 2010; Struthers, 2015). 
Belirtilen bu hususlardan yola çıkılarak insan haklarına ve özgürlüklerine saygılı/duyarlı ve bu haklara ve bunların ihlal alanlarına -ulusal/uluslararası çerçevede- ilişkin yeterli farkındalığa sahip eğitimcilerin yer alacağı kurumlarda, insan haklarının gerçek yaşam deneyimleri ile işletilmesinin, bunların erken yaşlardan itibaren çocuklar tarafından içselleştirilmesinin ve bu vesile ile de toplumsal yaşamın insan haklarına duyarlı bir dokuya sahip olmasının mümkün k1lınabileceği düşünülmektedir. Jennings (2006), eğitimci eğitiminin ve yeterliliklerinin -bilhassa sınıf öğretmenlerinin ve adaylarınındeğerlendirilmesinde insan hakları çerçevesinden yararlanılması gerektiğine dikkat çekmiştir. İnsan haklarına ilişkin duyarlılı̆̆ın kazandırılmaya başlanacağı bir eğitim dönemine hitap eden geleceğin sınıf öğretmenlerinin bu noktada, ulusal ve uluslararası alanda meydana gelen insan hak ve özgürlük ihlallerine ilişkin farkındalık düzeylerinin incelenmesinin önemli bir gerekliliği ifade ettiği düşüncesindeyiz. Burridge ve Chodkiewicz (2017), öğrencilerin insan haklarının hâkim olduğu bir okul kültüründe bulunmaları ve hakları gerçek yaşantılarla içselleştirebilmeli için eğitimcilerin hizmet içi ve öncesinde profesyonellerce insan hakları ve eğitimi konularında eğitilmeleri gerektiğini belirtmişlerdir. Belirtilen bu görüşlere paralel olarak 2.03.2021 tarihinde ülkemiz kamuoyu ile paylaşılmış olan İnsan Hakları Eylem Planı'nın (2021) ortaya koyduğu vizyon çerçevesinde tüm kamu görevlilerinin insan hakları konusundaki farkındalıklarının geliştirilmesi, ilk ve ortaöğretimin bu konuda önemle ele alınacak eğitim kademeleri olduğu, eğitim unsurlarının bu konuya duyarlı dizayn edilmesi ve eğiticilerin eğitilmeleri gerektiği, yükseköğretimde bu konunun incelenmesine ve öğretilmesine yönelik akademik çalışmaların gerçekleştirilmesi gerektiği ve insan hakları eğitiminin geliştirilmesi ve yaygınlaştırılması gibi hususlara yer verilmiş olduğu görülmektedir

$\mathrm{Bu}$ doğrultuda araştırmada;

-Türkiye'deki eğitim fakültelerinin sınıf öğretmenliği bölümünde, çeşitli sınıf kademelerinde öğrenim görmekte olan sınıf öğretmeni adaylarının temel insan hak ve özgürlüklerinin ulusal ve uluslararası ölçekteki ihlal alanlarına ilişkin farkındalık durumlarının belirlenmesi,

-Bu ihlallerin olası gerekçelerine ve ihlallerin ortadan kaldırılmasına yönelik sunulabilecek çözüm önerilerine ilişkin tespitlerinin belirlenmesi amaçlanmıştır.

\section{Yöntem}

$\mathrm{Bu}$ bölümde araştırma modeline, çalışma grubuna, veri toplama araçlarına, verilerin toplanması, analizi ve etik hususlara bağlılığa yönelik olarak gerçekleştirilen çalışmalara ait açıklamalar yer almaktadır.

\section{Araştırma Modeli}

Araştırma, nitel araştırma yaklaşımına uygun olarak gerçekleştirilmiştir. Miles ve Huberman (1994) nitel araştırma yaklaşımına ilişkin olarak sayısal ifadelerden ziyade sözel ifadelerin kullanıldığ 1 , sosyal bilim araştırmalarında sıklıkla kullanılan ve verileri de genelleme amacı gütmeden sağlam bir temel ve zengin bir açıklama olanăg sunan bir yaklaşım ifadelerini kullanmıştır. Bu araştırma kapsamında, sınıf öğretmeni adaylarının insan hak ve özgürlüklerinin ihlal alanlarına ve buna ilişkin nedenler ve çözüm önerisi tespitlerine yönelik bilimsel nitelikte bir açıklama argümanının ortaya konmasına gayret edilmiştir. Bu süreçte gerek katılımcılar tarafından belirtilen hak ihlalleri alanlarında gerekse diğer bulgulara ilişkin kategori alanlarında sayısal veriler öncelikli veriler olarak görülmemiştir.

\section{Çalışma Grubu}

Araştırma, Türkiye'nin çeşitli üniversitelerinin eğitim fakültelerindeki sınıf öğretmenliği bölümünde öğrenim görmekte olan toplam 702 öğretmen adayı ile gerçekleştirilmiştir. Araştırma kapsamında yer alan adayların belirlenmesinde, ölçüt örneklem yönteminden yararlanılmıştır. $\mathrm{Bu}$ doğrultuda belirli ölçütlere uygun ve araştırmaya katılımda gönüllü kişiler araştırma sürecine dâhil edilmiştir. Bu ölçütler adayların; lisans öğrenimleri süresince insan hakları eğitimi almamış ve/veya 
doğrudan temel insan hakları ve özgürlükleri ile ilişkili konuları içeren bir lisans dersine katılmamış olmaları, temel insan hakları ve özgürlükleri konusunda yürütülmüş/yürütülmekte olan bir proje çalışmasında daha önce yer almamış veya hâlihazırda yer almıyor olmaları ve insan hak ve özgürlükleri çerçevesinde faaliyet yürüten herhangi bir derneğe ve kuruluşa kayıtlı üyeliklerinin bulunmaması olarak belirlenmiştir.

\section{Veri Toplama Araçları}

Araştırma verilerinin edinilmesinde, sınıf öğretmeni adayları tarafından oluşturulan, temel insan hakları ve özgürlükleri konusundaki bilgilerini, bunların ihlallerine ilişkin gözlemlerini ve örnek yaşantılarını, bu ihlallerin olası nedenlerine ve çözüm yollarına ilişkin değerlendirmelerini yansıttıkları düşünce yazısı metinlerinden (dokümanlarından) yararlanılmıştır. Katılımcılar tarafından oluşturulan dokümanlar, araştırma sürecinde bizzat araştırmacı tarafından ya da katılımcılar tarafından bireysel olarak oluşturulabilen, araştırılan olay, kişi veya durum hakkında kapsamlı ve doğrudan gözlemlenemeyecek hususlar hakkında bizlere zengin bilgilere erişme firsatı sunan nitel araştırmaların temel veri toplama araçlarıdır (Merriam, 2015; Patton, 2014).

\section{Verilerin Toplanması ve Analizi}

Araştırmanın nitel veri kaynağını oluşturan dokümanlar, 08.07.2019-29.12.2019 tarihleri arasında otuz altı farklı eğitim fakültesinde öğrenim görmekte olan toplam 702 sınıf öğretmeni adayı tarafından oluşturulmuş ve araştırmacı tarafından bütün dokümanların istifi gerçekleştirilmiştir. Benzer içerikte ve tekrara düşülmüş belgeler analiz sürecine dâhil edilmemiştir. Verilerin edinilmesi sürecinde, istifi gerçekleştirilen dokümanlar, içerik ve betimsel analize tabi tutulmuşlardır. Robson (2015) tarafından içerik analizi, dünyevi kavramları tanımlayabilme ve açıklayabilme amacına hizmet eden; kodlanmış ortak akıl ve saf hale getirilmiş yollar olarak tarif edilmiştir. Bu doğrultuda analizi gerçekleştirilen dokümanlardan edinilen veriler; öğretmen adaylarının temel hak ve özgürlüklerin ulusal ve uluslararası çerçevedeki ihlal alanlarına yönelik düşünceleri, bu ihlallerin bir öğretmen adayı olarak gerekçelerine ilişkin değerlendirmeleri ve bunların gerek ülkemiz gerekse de küresel manada önüne geçilebilmesine yönelik önerileri olmak üzere üç temel bağlamda irdelenmiştir. Verilerin analizi sürecinde, yüksek lisans düzeyinde bağımsız bir araştırmacı tarafından da oluşturulan kategorilerin analiz teyidi yoluna gidilmiştir. Bu aşamada gerçekleştirilen teyt işleminde, bağımsız araştırmacı tarafında benzer içeriklere sahip dokümanlar dışında kalan belgeler sunulmuş ve bu noktadaki örnek kod ve kategori başlıklarının teyidi alınmıştır.

\section{Araştırma Etiği}

Araştırma sürecinde, etik hususların gereklerine, verilerin ve analiz süreçlerinin geçerliliğinin sağlanmasına ve güvenirliğin yüksek oranda tesisine yönelik çeşitli çalışmalar gerçekleştirilmiştir. Bu eksende, araştırma kapsamında gerçekleştirilecek veri toplama süreçleri için etik kurul incelemesine başvurulmuş ve gerekli araştırma izni için kurul onay raporu alınmıştır. Araştırma verileri -katılımcılar tarafindan oluşturulan dokümanlar- eğitim fakültelerinde görevli kişilerin destekleri ile yüz yüze uygulama ile edinilmiş̧ir. Bu kapsamda, katılıma gönüllük esas alınarak, belirlenen ölçütlere uygun adaylar çalışma konusu hakkında bilgilendirilmişlerdir. Dokümanlara doğrudan ulaşmış olmanın önemi, belgelerin araştırma bağlamı dışından elde edilmesi durumunda, gerek doğrulukları ve güvenilirlikleri gerekse de dokümanların sahip olabileceği potansiyel eğilimler açısından oluşabilecek ciddi sorunlar göz önüne alındığında net bir biçimde görülecektir (Robson, 2015).

Katılımcılar tarafından oluşturulan yazılı dokümanların analizi sürecinde, bağımsız bir araştırmacıdan da analiz teyitleri alınmıştır. Creswell'e göre (2014), araştırma verilerinin bu şekilde asıl araştırmacı dışında bağımsız araştırmacıların perspektiflerinden incelenmesi sayesinde, gerçekleştirilen nitel araştırmanın bütününe yönelik geçerliliğin artırılacağı ön görülmüştür. $\mathrm{Bu}$ noktada araştırma kapsamında dokümanlar, oluşturulan kategori başlıklarının bütünsellik göstermesi ve farklı kişiler tarafından da oluşturulabiliyor olup olmamasının kontrolü amacıyla birisi bağımsız olmak üzere iki uzman tarafından ayrı ayrı incelenmiştir. Patton (2014), veri setinin içten bakıldığında 
kategorilerin tutarlılık göstermesi, dışardan bakıldığında bir bütünü yansıtması ve başka kişiler tarafından da aynı veri setinden benzer başlıklara ulaşılabilmesi gerektiğini ifade etmiştir. Bu noktada verilerin, bütünsellik ve tutarlılık kontrolünün gerçekleştirilerek araştırma bulgularının geçerliğinin ve güvenirliğinin daha da üst düzeye taşındığını söylemek mümkündür.

Araştırma bulguları, sınıf öğretmeni adaylarının doğrudan ifade kesitleri ile desteklenerek sunulmuştur. $\mathrm{Bu}$ ifadelerde katılımcıların kişisel bilgilerine yer verilmemiş, her bir katılımcı "ÖA1, ÖA5..." kodları ile belirtilmiştir.

\section{Bulgular}

Araştırma kapsamında edinilen bulgular, sınıf öğretmeni adaylarının dünyada ve Türkiye'de yaşanılan temel insan hak ve özgürlüklerinin ihlal alanlarına, bu ihlallerin olası neden dinamiklerine ve bunların önlenmesine yönelik çözüm önerilerine yönelik tespitleri olmak üzere üç farklı ana başlık altında sunulmuştur.

\section{Dünya'da ve Türkiye'de Temel İnsan Hak ve Özgürlüklerinin İhlal Alanlarına Yönelik Bulgular}

Sınıf öğretmeni adaylarının dünyada ve Türkiye'de yaşandığını düşündükleri temel hak ve özgürlük alanlarına ilişkin bulgular Tablo 1'de ve Tablo 2'de sunulmuştur. Tablolarda frekans değerleri, bu tespitlerin hangi hak alanlarında yoğunlaştığının gösterilmesi amaciyla sunulmuştur. Tablo 1'de sınıf öğretmeni adaylarına göre dünyada en çok ihlal edilen temel insan hak ve özgürlük alanlarına ilişkin tespitleri yansıtılmıştır.

Tablo 1

Dünya'da Insan Haklarl ve Özgürlüklerine Yönelik İhlal Alanlart

\begin{tabular}{|c|c|c|c|}
\hline İ́hlal Edilen Temel Hak ve Özgürlükler & $\mathbf{f}$ & İhlal Edilen Temel Hak ve Özgürlükler & $\mathbf{f}$ \\
\hline Yaşama Hakkı & 588 & Çalışma ve Adil Kazanç Hakkı & 156 \\
\hline Eğitim Hakkı & 533 & Ekonomik Haklar & 136 \\
\hline Çocuk Hakları & 494 & Temiz Çevre Hakkı & 122 \\
\hline Ayrımcilıktan Korunma & 464 & Siyasal Haklar & 115 \\
\hline Sağlık Hakkı & 391 & Bilgi Edinme ve Haberleşme Hakkı & 104 \\
\hline Vücut Bütünlüğü ve Dokunulmazlık & 379 & Emek ve Emekçi Hakları & 96 \\
\hline Düşünce ve İfade Özgürlüğü & 366 & Seçme ve Seçilme Hakkı & 93 \\
\hline Din ve Vicdan Özgürlüğü & 359 & Toplanma ve Gösteri Hakkı & 88 \\
\hline Barınma Hakkı & 355 & Mülkiyet Hakkı & 88 \\
\hline Özgürlük ve Güvenlik Hakkı & 353 & Vatandaşlık Hakkı & 87 \\
\hline İstismarından Korunma (çocuk) & 349 & Kamu Hizmetine Girmede Liyakat & 85 \\
\hline Kadınlara Şiddet & 335 & Engelli Hakları & 81 \\
\hline Beslenme Hakk1 & 324 & Dil Özgürlüğü & 72 \\
\hline Mültecilik Hakları & 302 & Mülkiyet ve Konut dokunulmazlığı hakkı & 61 \\
\hline İşkence ve Kötü Muamele Yasağ1 & 273 & Basın Özgürlüğü & 55 \\
\hline Özel Hayatın Gizliliği & 266 & Unutulma Hakk1 & 54 \\
\hline Eşitlik ve Adalet Hakkı & 255 & Nafaka ve Tazminat Hakkı & 53 \\
\hline Cinsiyet Ayrımcılığından Korunma & 200 & Mobbing & 43 \\
\hline Psikolojik Şiddetten Korunma & 198 & Bilim ve Sanat Hakkı & 32 \\
\hline Adil Yargılanma ve Savunma Hakkı & 188 & Barış Hakkı & 20 \\
\hline Seyahat Etme ve Ulaşım Hakkı & 167 & Serbest Dolaşım Hakkı & 7 \\
\hline
\end{tabular}

Tablo 1 incelendiğinde katılımcıların, dünya üzerinde en çok yaşam hakkı, eğitim hakkı, çocuk hakları, ayrımcılıktan korunma, sağlık hakkı ve vücut bütünlüğ̈̈ ve dokunulmazlığı hakkının ihlal edildiğini belirtikleri görülmektedir. Diğer taraftan dil özgürlüğüu, vatandaşlık, basın özgürlüğü, bilim ve sanat hakkı, kamuda liyakat, bilgi edinme ve haberleşme hakkı gibi alanlara ilişkin ihlallerin daha az bir katılımcı bölümü tarafından ifade edilmiş olduğu görülmektedir. 
Tablo 2'de sınıf öğretmeni adaylarına göre Türkiye'de en çok ihlal edilen temel insan hak ve özgürlük alanlarına ilişkin tespitleri yansıtılmıştır.

Tablo 2

Türkiye'de Insan Haklart ve Özgürlüklerine Yönelik İhlal Alanları

\begin{tabular}{|c|c|c|c|}
\hline İhlal Edilen Temel Hak ve Özgürlükler & $\mathbf{f}$ & İhlal Edilen Temel Hak ve Özgürlükler & $\mathbf{f}$ \\
\hline Eğitim Hakk1 & 684 & İşkence ve Kötü Muamele Yasağ1 & 375 \\
\hline Cinsel Dokunulmazlık & 677 & Mültecilik Hakları & 371 \\
\hline Çocuk Hakları & 668 & Adalet Hakkı & 367 \\
\hline Düşünce ve İfade Özgürlüğü & 659 & Ekonomik Haklar & 361 \\
\hline Şiddetten Korunma (Kadın) & 645 & Temiz Çevre Hakkı & 361 \\
\hline Yaşama Hakkı & 642 & Barınma Hakkı & 266 \\
\hline Ayrımcilıktan Korunma & 594 & Beslenme Hakk1 & 258 \\
\hline Adil Yargılanma ve Savunma Hakkı & 588 & Dil Özgürlüğü & 250 \\
\hline Özgürlük ve Güvenlik Hakk1 & 575 & Engelli Hakları & 239 \\
\hline Eșitlik Hakk1 & 558 & Bilgi Alma ve Haberlessme Hakkı & 236 \\
\hline Basin Özgürlüğg̈ & 490 & Seçme ve Seçilme Hakkı & 234 \\
\hline Özel Hayatın Gizliliği & 486 & Mülkiyet Hakkı & 224 \\
\hline Din ve Vicdan Özgürlüğü & 483 & Seyahat Etme ve Ulaşım Özgürlüğü & 222 \\
\hline Psikolojik/Duygusal Şiddet & 459 & Vatandaşlık Hakk1 & 222 \\
\hline Çalışma ve Adil Kazanç Hakkı & 446 & Sendikal Haklar & 221 \\
\hline Toplanma, Yürüyüş ve Gösteri Hakk1 & 444 & Mobbing & 220 \\
\hline Emek ve Emekçi Hakları & 439 & Sağlık Hakkı & 198 \\
\hline Bilim ve Sanat özgürlüğü & 438 & Vergi Adaleti & 193 \\
\hline Vücut Bütünlüğü ve Dokunulmazlık & 425 & Tüketici Hakları & 184 \\
\hline Kamu Hizmetine Girmede Liyakat & 419 & Konut Dokunulmazlı̆̆ı Hakkı & 180 \\
\hline Örgütlenme Hakk1 & 408 & Nafaka ve Tazminat Hakk1 & 154 \\
\hline
\end{tabular}

Tablo 2 incelendiğinde ise daha büyük oranda katılımcı arasında, ülkemizde yaşanan insan hakları ihlalleri konusunda bir görüş birliğinin mevcut olduğu görülmektedir. Bu hak ihlalleri arasında en yoğun olarak eğitim hakkının, cinsel dokunulmazlık hakkının, çocuk haklarının, düşünce ve ifade hürriyeti hakkının, şiddetten korunma hakkının, yaşama hakkının, ayrımcılıktan korunma, adil yargılanma ve savunma, özgürlük ve güvenlik, eşitlik ve basın hürriyeti hakkının katılımcıların büyük bir kesimi tarafından ifade edilmiş olduğu görülmektedir. Diğer taraftan katılımcıların çok daha az bir kesimi tarafından ülkemizde sağlık hakkının, vergi adaletinin, tüketici haklarının, konut dokunulmazlı̆̆ı, nafaka ve tazminat hakkının çok daha az yaygınlıkta ihlal edilen haklar olarak ifade edildiği görülmektedir.

\section{Temel İnsan Hakları ve Özgürlüklerine Yönelik Olası İhlal Nedenlerine İlişkin Bulgular}

Tablo 3'de sınıf öğretmeni adaylarının temel insan hak ve özgürlüklerinin ihlal gerekçelerine yönelik tespitlerinden hareketle oluşturulmuş olan kategori ve kodlara yer verilmiştir. Tablo 3'de yer alan kategorilere ilişkin bulgular bir bütün halinde ele alınarak sunulmuş ve bunlara ilişkin doğrudan katılımcı ifadelerinden kesitler ile de görünür kılınmıştır. 
Tablo 3

Temel İnsan Haklarl ve Özgürlüklerine Yönelik İhlal Gerekçelerine Ait Kod ve Kategoriler

\section{Kategoriler}

Ekonomik Sebepler

Adetler, Gelenekler, Görenekler ve Toplumsal Yargilar

Çalışma Hayatındaki Zorluluklar ve İstihdam Problemleri

Eğitimsizlik ve Farkındalık Kazandırıcı Faaliyetlerin Yetersizliği

Antidemokratik Kamu Yönetimi Anlayışları

Otoriter Yaklaşımların Toplumsal Kabulü ve Popülerliği

Küresel Hesaplaşmalar ve Çıkar Çatışmaları

Hoşgörüsüz, Ötekileştirişi ve D1şlayıcı Yaklaşımlar

\section{Aile Planlamasına İlişskin Bilinçsiz} Tutumlar

Kontrolsüz ve Plansız Göç Politikaları

Sosyoekonomik Farklılıklar Arası Mesafelerin Artmas

Eğitim Sistemindeki Eksiklikler ve Yanlış Politikalar

\section{Kodlar}

Gelir yetersizliği, kazanç elde etmek için illagal yollara başvuru, temel ihtiyaçların giderilememesi, refah düzeyinin düşüklügüu, kolay kazanç elde etme isteği, gelir adaletsizliği

Toplumsal cinsiyet eşitsizliği, çocukların birey olarak kabul görmemesi, şiddeti onaylayan kültürel söylemler ve unsurlar, ataerkil toplumsal yapilar

İşsizlik, mobbing, çalışma ortamlarında cinsiyet ayrımcılığ kamuda liyakatsiz işe alımlar, uygun olmayan çalışma ortamları

İnsan hakları konusunda toplumsal bilinçsizlik, yerel yönetim çalışmalarının eksikliği, kamuspotlarının yetersizliği, üniversitelerin topluma hitap etmemesi

Yasaklar, baskıcı tutumlar, şaffaf olmayan seçimler, kamuda liyakat sorunu, adaletsiz bütçe dağılımları, kaynakların israfi kullanımı

Şiddeti övme ve teşvik etme, ataerkilliğin desteklenmesi, bireysel silahlanma isteği, agresif söylemlerin desteklenmesi, bilinçsiz kitlesel hareketler ve eğilimler, ötekileştirici söylemlerin toplumsal desteği

Küresel çıkar çatışması, yayılmacı biçimde kaynak arayışları, siyasal çatışma geçmişi, ülkelerarası soğuk mücadeleler, küresel siyasi birliktelikler, uluslararası kuruluşların yetersizliği

Hoşgörüsüzülük, farklılıklara toleranssızlık, çeşitli sebeplerle ayrımcılık, tek tipçi anlayış, 1rkçı yaklaşımlar ve söylemler

Çok çocukluluk, cinsiyet ayrımcılığı ve toplumsal beklentiler, çocuk izlemlerinin yetersizliği, yanlış nüfus politikaları ve teşvikler

Kaynakların göçmenlere ayrılması, sınır kapılarının kontrolsüz açılması, göçmenlere sunulan hizmetler

Haksız zenginleşme, artan fakirleşme, sosyal yardımlaşma ve dayanışmanın azalması, sosyal yardımların yetersizliği ve adaletsizliği

Okullardaki antidemokratik yönetim anlayıșı, insan hakları eğitimine yönelik içerik yetersizliği, eğitim kurumlarının hak temelli olmayan tasarımları, her çocuğa sunulmayan eşit eğitim olanakları, teknolojik altyapının bölgesel olarak eşit dağılmayışı, atama ve yükselme sistemindeki liyakate dayalı olmayan uygulamalar, öğretmenlerin bilinçsizliği, çocuk hakları eğitiminin eksikliği

Katılımcı sınıf öğretmeni adaylarının temel insan hakları ve özgürlük ihlallerinin nedenlerine ilişsin tespitleri, on iki farklı başlık altında kategorik hale getirilmiştir. Bu kategori başlıkları incelendiğinde öğretmen adayları tarafindan ekonomik, sosyal, kültürel ve siyasal bağlamdaki birçok unsuru insan hak ve özgürlüklerinin temel ihlal nedenleri arasında gördükleri anlaşılmaktadır. Katılımcıların bu kapsamdaki tespitlerine bakıldığında, ekonomik geçim sıkıntılarının ve işsizliğin, toplumsal yaşamdaki geleneksel anlayışların, örf ve adetlerin, insana verilen değerin, kamu yönetimindeki otoriter tutum ve anlayışların, farklılıklar kabul etmeyen yaklaşımların, plansız nüfus politikaları ve teşviklerinin, eğitim sistemlerindeki eksikliklerin ve yanlış politikaların insan hak ve özgürlüklerinin esas ihlal gerekçeleri olarak görüldüğü anlaşılmaktadır. Bu unsurlara yönelik tespitleri görünür kılmak için katılımcıların doğrudan ifadelerinden bazı bölümlerin gösterimine gerek 
duyulmuştur. İlgili kategori başıkları ile ilişkili katılımcıların doğrudan ifadelerinden bazı kesitler şu şekildedir:

ÖA8; "Çoğu insan birçok kaygı içinde yaşıyor; gelir kaygısı, gelecek kayısı, iş kaygısı vs. toplumun refah düzeyi düşük olması hak ihlallerinin bence en temel nedenlerinin başında geliyor."

ÖA82; "Bana göre bu hak ihlallerinin temelinde insanlartn doyumsuz olmalart ve egolart yatıyor. Sevgiye ve cinselliğe olan doyumsuzluktan dolayı kadınlar öldürülüyor. Paraya olan doyumsuzluktan dolayı işçiler çalışma saatlerinin çok üzerinde çalıştırılıyor."

ÖA196; "Çocuk istismarının hiçbir şekilde kabul edilebilir bir nedeni ve bahanesi olamaz fakat gelir düzeyi düşük aileler, aile içi geçimsizlik olan aileler, mutsuz olan aileler istismarın daha çok görüldü̈̆̈̈ durumlardır. Istismar gerçekleştiren bireyler sırf kendi gereksinimlerini karş̧layabilmek için çocuğu ne yazık ki kullanırlar. Yani kendi gereksinimlerini çocuklarınkinden üstün tutarlar..."

Katılımcı sınıf öğretmeni adaylarının insan hakları ihlallerinin temel neden dinamiklerine ilişkin tespitleri arasında en yaygın olarak ifade edilen unsurlardan bir tanesi $-\ddot{O} A 8, \ddot{O} A 82$ ve $\ddot{O} A 196$ örneklerinde olduğu gibi- ekonomik imkânlar, koşullar ve toplumların refah düzeyleridir. Bu noktada katılımcıların, insan haklarının korunması, gelişmesi ve ihlallerin önlenmesinde, ekonomik şartların ve refahın iyileştirilmesine yönelik çalışmaların büyük öneme sahip olduğuna yönelik bir düşünce yapısında oldukları söylenebilir.

ÖA22; "Bu konuda en önemli nedenin ben eğitim olduğunu düşünüyorum. Eğitim sistemimiz insanlara "insan" olmayı ögretmekte yetersiz kalmakta. Dolayısıla kimse kimsenin haklarına veya özgürlük alanlarına saygl göstermiyor..."

ÖA185; "Bu ihlallerin sebebi ülkelerde hâkim olan eğitimsiz ve cahil toplumların varlığıdır. Küçük yaşlardan itibaren sorgulamadan kalıplaşmış düşünce ve fikirlere inaniyoruz ve maalesef uyguluyoruz..."

ÖA341; "Ülkemizde ögrretmenler bu konuda çok deneyimsiz. Yani çocukları bu konuda duyarlı yetiştirecek ögretmenlerimiz yok. Biz bile halen bu konuda iyi bir eğitim almış değiliz... Stajda da gözlemliyorum mesela bu konular o kadar yüzeysel geçiliyor ki... Bence eğitim sistemimiz bu konuda iyileştirilmeli öncelikle..."

İnsan hakları ihlallerinin temel gerekçeleri arasında $-\ddot{O} A 22$, ÖA185 ve ÖA341 örneğinde olduğu üzere- eğitimsizliğin, toplumsal farkındalık eksikliğinin, eğitim kurumlarında insan hakları ve çocuk hakları eğitiminin yetersizliğinin, eğitimcilerin bu konudaki farkındalık/sorumluluk düzeylerinin düşüklügünün ve okullarda hak temelli bir kültürün hâkim olmayışının katılımcılar tarafından yaygın şekilde ifade edildiğinin belirtilmesi gerekmektedir.

ÖA60; "Toplumumuzda o kadar çok yerleşmiş anlayış var ki... Kadınlar şöyle yapamaz, çocuklar konuşmaz, geç saatte dışarı çıkılmaz... Saymakla bitmez. Özetle en büyük problem toplumun ta kendisi... Kalıplarını kırmak istemeyen insanlarla insan haklarını konuşamazsınız..."

ÖA162; "Birçok insan ülkesinde rahatça istediğini ne düşündüğ̈̈n̈̈ söyleyemiyor, ne şekilde yaşamak istediğine karar veremiyor. Hoşgörüsüzlük bence insan hakları ihlallerinin en önemli sebebi... Ve farklılıklara tahammülün olmaması..."

ÖA258; “...Toplum olarak hak ihlallerinin ortaya çıkış nedenini başlıca olarak empati yeteneğimizin düşük olmasına bağllyorum. Çünkü insanların haklarını ihlal ederken onları insan yerine koymazken onların ne hissettiğini hiç düşünmüyoruz ve kendime yapılsa ne yapardım demiyoruz. Bu duyarsızlıkla da her türlü insanın, çocuğun hayvanın bir takım haklara sahip olduğunu 
göz ardı ediyoruz. Toplum olarak bir de kabulleniş var tabi; "bana dokunmayan yılan bin yıl yaşasın" düşüncesindeyiz..."

Katılımcıların -ÖA162, ÖA258 ve ÖA60 örneğinde olduğu gibi- insan hakları ve temel özgürlüklerin ihlal temel gerekçeleri arasında, insanların farklılıklara tahammülsüzlükleri, dışlayıcı, ayrıştırıcı ve hoşgörüsüz tutumları, toplumsal cinsiyet eşitsizliği temelli anlayışları, toplumsal algıları ve yerleşik tutumları ifade ettikleri görülmektedir. Belirtmek gerekmektedir ki bu kapsamda ifadeler büyük bir katılımcı kitlesi tarafından ifade edilmiştir.

ÖA77; "Bence bu suçların ve ihlallerin temelinde insanların; iktidar kaygıları, özgüven problemleri, narsist düşünce yapıları, aile içi ve okul eğitiminin eksikliği, örf ve adetler gibi etkenler yatmaktadir..."

ÖA523; "Bu ihlalleri ben biraz yetiştirme tarzındaki yanlışlara bağllyorum. Çünkü çocukluktan itibaren hep bastırllarak, susturularak, bir şekilde hep birilerine boyun eğerek büyüyoruz. Bunun sonucunda da kendimize herhangi bir hak ihlali yapıldiğl takdirde de kendimizi savunup ifade edemiyoruz. Korkak ve hakkın aramayan bireyler yetiştiriyoruz. Sonra da kendinden en ufak yüksek bir insan gördüğünde hemen karşısında ezilip büzülme eğilimi gösteriliyor.”

ÖA453; "Ülkemizdeki ihlallerin başında bana göre kişilerin özgürlük haklarının ihlali gelmektedir. Demokrasiden özgürlükten bahsediliyor olsa da gerçekte durum böyle değil. Insanlarımız birilerine bă̆ıml yaşamakta. Istediği zaman istediğini yapamamaktadır. Bu da bilinçsiz bireyler yetişmesine yol açmaktadır. Mesele bence otorite, baskı ve korku..."

ÖA 136; “Insanlar siyasetçilerin despot yaklaşımlarını sevebiliyor ve örnek alabiliyorlar. Böyle olunsa birbirlerine karşıda haklara saygı duymak yerine aynı üslupla yaklaşarak baskınlı kurmaya çallşlyorlar... Yöneticiler şu dönemde zaten en üst düzeyde otorite ve kontrol sağlamak isteğindeler... Biz öğretmenlere çok iş düşecek ilerde eminim..."

ÖA453 ve ÖA136 örneklerinden de anlaşılacağı üzere katılımcılar tarafından, otorite ve erk sahibi yöneticilerin sahip oldukları tutumların ve bunların toplumu oluşturan bireyler tarafından benimsenmesinin de insan hakları ihlallerinin ve temel özgürlüklerin kısıtlanmasının altında yatan temel sebeplerden olarak değerlendirildiği görülmektedir.

\section{Temel İnsan Hakları ve Özgürlük İhlallerinin Önlenmesindeki Olası Çözüm Yollarına İlişkin Bulgular}

Tablo 4'de sınıf öğretmeni adaylarının küresel ve yerel çerçevede yaşanan insan hakları ve özgürlük alanı ihlallerinin önlenmesine yönelik öneri tespitleri doğrultusunda oluşturulmuş kategorilere yer verilmiştir. Tablo 4'de yer alan kategorilere ilişkin bulgular bir bütün halinde ele alınarak sunulmuş ve bunlara ilişkin doğrudan katılımcı ifadelerinden kesitler ile de görünür kılınmıştır. 
Tablo 4

Temel İnsan Hakları ve Özgürlüklerine Yönelik Ihlallerin Önlenmesine Yönelik Çözüm Önerileri

\section{Çözüm Önerilerine İlişkin Kategori Başıkları}

\section{Yaşam Hakkı}

Can güvenliğine yönelik tedbirlerin genişletilmesi

Can güvenliğine yönelik caydırıcı nitelikte cezaların yasalaştırılması

Eğitim ve Öğrenim Hakkı

Eğitim sistemlerinde firsat eşitliği odaklı düzenlemeler

Toplumsal kesimlerin tamamına yönelik insan hakları eğitimi

Eşitlik Hakkı

Gelir adaletinin sağlanmasına yönelik tedbirler

Eşitlikçi ve adil bir toplumsal yaşamın tesisine yönelik politika çalışmaları

Kamu idaresinde demokrasi kültürünün yerleștirilmesine yönelik çalışmalar

Yönetenlerin insan haklarına bağlılıklarının tesisi

\section{Düşünce ve İfade Hürriyeti Hakkı}

Basın Özgürlüğünün ve Tarafsızlığının Tesisine Yönelik Düzenlemeler

Kişilerin tüm alanlarda kendini rahatça ifade edebilmesine yönelik tedbirler

Korunma ve Sağlık Hizmetlerine Erişim Hakkı

Kadınlara ve çocuklara yönelik koruyucu tedbirlerin genişletilmesi

Aile planlaması konusunda toplumsal farkındalığın olușturulması

Göç ve sağlık hizmeti politikalarının insan hakları temelinde geliștirilmesi

Katılımcı sınıf öğretmeni adaylarının temel insan hak ve özgürlük ihlallerinin önlenmesine yönelik tespitleri on bir farklı başlık altında kategorik hale getirilmiștir. Bu kategori başlıkları incelendiğinde öğretmen adaylarının hak ihlallerinin önüne geçilebilmesine ilişkin olarak can ve mal güvenliğine yönelik tedbirlerin, caydırıcılığı yüksek cezai uygulamaların, eğitim sistemlerinde yapılacak düzenlemelerin, toplumsal farkındalığın geliştirilmesine yönelik hak eğitimlerinin, basın özgürlüğünün tesisine yönelik düzenlemelerin, eşitlikçi ve adil bir toplumsal yapıya yönelik politika çalışmalarının, kadınlara ve çocuklara yönelik ek koruyucu tedbirlerin getirilmesi, yönetimde demokrasinin hâkim kılınmasına yönelik çalışmaların gerçekleştirilmesi, aile planlamasına ilişkin toplumsal farkındalığın geliştirilmesi ve göç/sağlık hizmeti politikalarının insan hakları çerçevesinde geliştirilmesi doğrultusunda öneriler ortaya koydukları görülmüştür. Bu unsurlara yönelik tespitleri görünür kılmak için katılımcıların doğrudan ifadelerinden bazı bölümlerin gösterimine gerek duyulmuştur. İlgili kategori başlıkları ile ilişkili katılımcı doğrudan ifadelerinden bazı kesitler şu şekildedir:

ÖA57; "Insanların hak ve özgürlüklerine müdahale edilmemesi gerekmektedir. Bunun için ülkedeki insanların ve konunun başındaki insanların daha bilinçli olması gerekmektedir. Bu yüzden herkese bu konuda eğitim verilmesi gerektiğini düşünüyorum."

ÖA159; "Çocuklarımız maalesef öyle bir eğitim sisteminden öyle bir sinav sisteminden içinden geçiyorlar ki insan haklarını bırakın yaşamayı doğru düzgün öğrenmiyorlar bile... Okullar da böyle iken diğer insanların bu konuda daha duyarlı olmasını beklememek lazım... O yüzden toplumun bu konuda eğitimden geçmesi lazım."

ÖA684; "Ben geleceğin sinıf ögretmeni olarak öğrencilerime de haksızlı karşısında susmamayı ögreteceğim. Ayrıca onların da isteyerek ya da istemeyerek yaptıkları haksızlıklara susmayı doğrusunu güzel bir dille öğreteceğim. Bu konuda ĕ̆itim sistemimizin büyük eksikleri var bana göre. Bu konuların eğitim yaşamım boyunca hiçbir zaman önemle ele alındı̆̆ı olmadı çünkü..."

ÖA362; "Hak ve sorumluluklar üzerine toplumu bilinçlendirici eğitimler yapılabilir. Bunu dişında haklart ihlal edilen insanlar ve çocukların devlet tarafindan koruma altına alınmaları ve tedbirlerin daha sıkı uygulanması gerekir. Hatta tedbirlerin olası her duruma karşı uygulamada olup ihlaller yaşanmadan önce azaltıcı ya da tamamen ortadan kaldırıcı etkide olması gerekir." 
Katılımcılara ait olan yukarıda yer alan doğrudan ifade kesitleri incelendiğinde (ÖA57, ÖA159, ÖA362 ve ÖA684), insan haklar1 ve temel özgürlüklerin korunmas1 ve bunların ihlallerinin önelenebilmesi noktasında anahtar rolün eğitime ait olduğunun belirtildiği görülmektedir. Eğitimin, insan hakları ve temel özgürlüklere saygı kültürünün toplumda hâkim kılınmasının temel yolu olduğunu ve ayrıca okulların insan hakları konusuna ilişkin duyarlıklardan ve insan haklarının öğretimi noktasındaki içerik unsurlarından yoksunluğuna işaret eden ifadelerin ortaya konmuş olduğu görülmektedir.

ÖA418; “...Yargının bağımsızlı̆̆ ilkesi korunmalı. Adil gelir dă̆ılımları sağlanmalı ve hiç kimse temel yaşam haklarına ulaşmaktan ve insan onuruna yaraşır bir yaşam düzeyine sahip olmaktan mahrum bırakılmamalı. Hukuk alanında köklü değişikliklere gidilmeli ve sistem güçlü olanı değil haklı olanı desteklemeli. Adil yargılamalar ve adil cezalar uygulanmalı. Sosyal devlet anlayışı benimsenmeli ve insanların mağdur edilmesinin önüne geçilmeli.”

ÖA641; “Insan haklarl ihlallerini önlemenin en önemli yolu kanun ve yasalardir bence. Kanun ve yasalar insan haklarına önem verir ve korumaya çalışırsa sorunların büyük bir kismı ortadan kalkacaktır. Yaşadığımız toplumda bir ihlale şahit olursak bunlara göz yummamalı ve gerekli yerlere hemen bildirmeliyiz."

ÖA145; "Ben özellikle kadın ve çocuk haklarının ihlal edilmesinin önüne ağır cezalar ile geçilebileceğini düşünüyorum. Maalesef bu konuda ki cezaların caydırıcıllğı düşük... O yüzden bu konudaki mağduriyetler bitmiyor..."

Katılımcıların bu konuda yine yoğun olarak ortaya koydukları tespitlerden bir diğeri, insan hakları ihlallerinin önlenmesinde hukuki alandaki çalışmaların ilerletilmesi ve bu konu bağlamında genişletilmesidir. Katılımcı doğrudan ifade kesitlerine bakıldığında (ÖA145, ÖA418 ve ÖA641), insan haklarının korunması ve ihlallerinin önlenebilmesi amacıyla yasama çalışmalarının artırılması, ceza adaleti sisteminin bu konuda ilerletilmesi ve adil yargılanma ve eşitlik prensiplerinin hâkim kılındığı bir hukuk sisteminin işe koşulması gerektiği gibi öneri tespitlerine vurgu yapıldığı görülmektedir.

ÖA682; "Bence bu konuda ilerleme kat edebilmek için önce devlet yetkililerinin insan haklarını gözeten kişiler olmalarını sağlamalıyız. Otoriter yaklaşımlara sahip olmayan, insanları baskılamayan ve özgürlükleri sinırlandırmayan birileri olmalılar ki toplumlar onları örnek alsınlar..."

ÖA98; "Bence insanlar temel geçim sıkıntılarını karşılayamadıktan sonra bu konularda duyarlılığı sağlayamazlar. Şuan birçok ülkede milyonlarca insan gelir adaletsizliğinin içerisinde... Bu insanlardan başkalarının haklarına özgürlüklerine saygılı davranmasını ne kadar bekleyebiliriz ki... O yüzden önce bu konuda eşitliği sağlayabilmeliyiz ki insan haklarını gerçekten konuşabilelim..."

Katılımcıların bir diğer öneri alanı olarak, kamu yönetiminde ve toplumsal yaşam refahına ilişkin unsurları ortaya koydukları görülmektedir (ÖA682 ve ÖA98). Bu doğrultuda birçok katılımcı tarafından insan hak ve özgürlüklerinin korunmasında ve bunlara yönelik ihlallerin önlenmesinde kamu yönetiminden sorumlu kişilerin bu konulardaki hassasiyetlerinin önemine değinildiği görülmüsşür. Ayrıca toplumsal yaşam içerisinde gelir adaletinin ve eşitliğinin liyakat temelinde sağlanmasının ve insanların belirli bir refah düzeyine kavuşturulmalarının insan haklarına ilişkin sorunların giderilmesindeki önemli yollardan bir tanesi olarak belirtildiği görülmüştür.

\section{Sonuç, Tartışma ve Öneriler}

Araştırma sonucunda, sınıf öğretmeni adaylarının uluslararası ve ulusal ölçekteki insan hakları ihlallerine yönelik belirli bir farkındalık düzeyine sahip oldukları sonucuna ulaşılmıştır. Bu noktada belirtmek gerekmektedir ki öğretmen adaylarının büyük bölümü arasında, ülkemizde yaşanan insan hakları ihlallerine ilişkin bir görüş birliği bulunmaktadır. Bu bulgunun edinilmiş olmasında, bazı temel hak ve özgürlük ihlallerinin uluslararası bağlama göre daha yaygın ve daha görünür olmalarının gerekçe oluşturabileceği söylenebilir. Edinilen diğer bir sonuç ise öğretmen adaylarının küresel ve 
yerel bağlamda yaşandığ 1 düşünülen insan hak ve özgürlüklerine ilişkin benzer tespitlerde bulunmuş olmalarıdır. Bu sonuç ekseninde katılımcılara yönelik olarak, ulusal ve uluslararası alandaki bilgi ve haber akışlarını paralel olarak takip ettikleri veya küresel ölçekte yaşanan hak ihlallerinin etki gücü ve alanı itibariyle ülkemizde de yaşanmasını temel dayanak olarak görüyor olmaları değerlendirmesinde bulunmak mümkündür. Bu öngörünün çıkış noktası ile benzer şekilde Leung ve Lo (2012) tarafından gerçekleştirilen bir araştırmada, öğretmenlerin sahip oldukları insan hakları anlayışları ile uluslararası insan hakları standartları arasında büyük bir boşluğun olduğu sonucuna ulaşılmıştır. Bu noktada gerçekleştirilen bu araştırmada öğretmen adaylarının, hak ihlallerine yönelik olarak ulusal ve uluslararası ölçekteki ihlallerin paralelliğine yönelik algıları dikkat çekmekte ve Leung ve Lo'ya (2012) ait araştırma bulguları ile kısmi bir tezatlığın varlığından söz edilebilir.

Araştırma sonucunda sınıf öğretmeni adaylarının, ulusal bağlamda en çok eğitim hakkının, cinsel dokunulmazlık hakkının, çocuk haklarının, düşünce ve ifade hürriyeti hakkının, şiddetten korunma hakkının, yaşama hakkının, ayrımcılıktan korunma, adil yargılanma ve savunma, özgürlük ve güvenlik, eşitlik ve basın hürriyeti hakkının; uluslararası bağlamda ise en çok yaşam hakkı, eğitim hakk1, çocuk hakları, ayrımcılıktan korunma, sağlık hakkı ve vücut bütünlüğü ve dokunulmazlığı hakkının ihlal edildiğini belirttikleri görülmüştür. Ancak adayların insan hak ve özgürlüklerinin ihlallerine yönelik gerekçelerin arasında adetleri, gelenek ve görenekleri, toplumsal yargıları ve yerleşik düşünce kalıplarını işaret etmelerine rağmen bunlardan kaynaklı olabilecek ihlal alanlarına ilişkin yeterli farkındalığa sahip olmadıkları sonucuna da ulaşılmıştır. Nitekim çocuk evlilikleri, kız çocuklarının sünneti, çok eşli evlilik vb. gibi konuların, öğretmen adayları tarafından ulusal ve uluslararası alanda varlığa sahip temel insan hakları ihlalleri arasında görülmemesi çarpıcı bir sonuç olarak değerlendirilmiştir. Varlı (2020), dünya çapında insan hakları ihlallerine ilişkin olarak genellikle düşünce ve ifade özgürlüğü, eğitim hakkı, yasalar önünde eşitlik, yaşam hakkı, işkenceye tabi tutulmama, zorla çalıştırılmama, toplanma ve örgütlenme özgürlüğü gibi hususların dile getirildiğini ancak bunların dışında kültürlerin içine gizlenmiş veya kültürler tarafından kabul görmüş insan hakları ihlallerinin var olduğunu ve bunların daha tehlikeli ve daha yaygın olduğunu belirtmiştir. Bu noktada sınıf öğretmeni adaylarının, bu çerçevede ele alınabilecek insan hak ve özgürlüklerine ihlallerine- ilişkin yeterli farkındalığa sahip olmadıklarını söylemek mümkündür.

Mesleki yaşamlarının ilk dönemlerinden itibaren uzun dönemler daha çok kırsal alanlarda görev yapmakta olan sınıf öğretmenlerinin, kültür, inanç, örf-adet, gelenek ve toplumsal alg1 unsurlarının yaşamda daha hakim olduğu bu bölgelerdeki insan hak ve özgürlük alanlarının ihlallerine yönelik daha fazla farkındalığa sahip olmaları gerekmektedir. Bu görüşü, sınıf öğretmenlerinin kırsal bölgelerde yaşayan çocuklara ve yetişkinlere rol model oldukları gerçeği ile gerekçelendirmek mümkündür. Jennings (2006), insan hakları ve insan hakları eğitimine ilişkin standartların birçok eğitimci açısından yabancı karşılandığına dikkat çekmiş ve bu standartların esas olarak, sınıf öğretmenleri söz konusu olduğunda uygulamaya yönelik becerilerin varlığına dayandığını ifade etmiştir. Dolayısıyla bugünün ve geleceğin sınıf öğretmenlerinin bu konudaki farkındalık durumlarının uygulama becerisi destekli olarak geliştirilmesi son derece önemli bir gerekliliktir. Bu gerekliliği destekler nitelikte Özbek (2017) araştırmasında öğretmenlerin, insan hakları ihlalleri, korunması ve insan haklarının korunmasında karşılaşılan sorunlar gibi uygulamaya yönelik konulara ait kazanımların öğrencilere en düşük düzeyde aktarılabildiklerini belirttikleri sonucuna ulaşmıştır.

Araştırmada dikkat çeken bir diğer sonuç, sınıf öğretmeni adaylarının insan hakları ve eğitimi konusundaki kişisel farkındalıklarını yeterli görmedikleri, yaşanmakta olan hak ihlallerinin temel gerekçeleri arasında eğitimsizliği, farkındalık kazandırıcı faaliyetlerin yetersizliğini ve eğitim sisteminin bu konudaki yetersiz unsurlarını gördükleri ve çözüm önerileri noktasında da buna paralel olarak eğitimsel düzenlemeleri ve insan hakları konusundaki toplumsal farkındalığın geliştirilmesine yönelik etkinlikleri işaret etmiş olmalarıdır. Bu sonuçlarla benzer yönde, sınıf öğretmenlerinin ve adaylarının insan hakları, vatandaşlık ve demokrasi eğitimi konularında ve bu içerikteki derslerde kendilerini alan bilgisi açısından yetersiz gördükleri, kaliteli bir insan hakları eğitimine ihtiyaç duydukları, bu konuda okullarda verilen eğitimlerin yetersiz olduğunu düşündükleri, erken yaşlardan itibaren çocuklara insan hakları, vatandaşlık ve demokrasi eğitimlerinin verilmesi gerektiğini 
düşündükleri gibi araştırma sonuçları ile ortaya konulmuştur (Ersoy, Balbağ ve Gündoğan Bayır, 2017; Gündoğdu, 2011; Gürel, 2016; Toprak ve Demir, 2017).

Araştırma sonuçları genel olarak değerlendirildiğinde, sınıf öğretmeni adaylarının ulusal ve uluslararası çerçevedeki insan hakleri ve özgürlük ihlallerine yönelik belirli bir farkındalığa sahip oldukları, ancak normlarda yer almayabilen bazı ihlallere yönelik -kültürel kökenli vb.- farkındalığa sahip olmadıkları sonucuna ulaşılmıştır. Adayların ayrıca, insan hakları ve özgürlüklerinin ihlal gerekçeleri ve bunlara yönelik öneriler hususunda da belirli farkındalığa sahip olduklarını ancak yine insan hakları, çocuk hakları ve eğitimi gibi konularda eğitim ihtiyaçlarının bulunduğunu söylemek mümkündür. Bu noktada bir öneriye yer vermek gerekirse, insan hakları ve özgürlükleri konusuna ilişkin olarak dünya üzerindeki politika çalışmalarında, öğretmen eğitiminde ve okul bazında bazı tedbirlerin acil olarak alınması gerektiği ifade edilmiştir (Leung ve Lo, 2012). Bu doğrultuda sınıf öğretmeni adaylarının insan hakları ve özgürlükleri, hak ihlalleri, çocuk hakları ve toplumsal cinsiyet eşitliği gibi konularda farkındalık kazandırıcı etkinliklere katılımlarının sağlanması gerekmektedir. Bu öneri ile benzer olarak Kwon ve diğg. (2020) araştırmalarında, üniversite öğrencilerinin insan hakları yaşantılarının zenginleştirilmesine yönelik sosyal etkinliklerin gerçekleştirilmesinin yararlı olacağına dikkat çekmişlerdir. Öğrencilerin ayrıca, insan hakları ve hak ihlallerine yönelik toplumsal yaşam içerisindeki farkındalıklarını artırmaya yönelik sosyal hizmet (proje, topluma hizmet vb.) çalışmalarının gerçekleştirilebileceği önerisinde bulunmuşlardır.

İnsan haklarına ve özgürlüklerine duyarlı bir toplumsal yapının inşasını hayata geçirecek kişiler arasında sınıf öğretmenlerinin de yer aldığını ifade etmek yerinde olacaktır. Bu noktada hizmet öncesi süreçten itibaren, geleceğin yetişkinlerini şekillendirecek olan bugünün öğretmen adaylarının bu konularda son derece bilinçli olmaları ve topluma bu konudaki duruşları ile örnek teşkil edebilmeleri gerekmektedir. Bu konuda yürütülecek tüm politika, hukuk ve eğitim alanlı çalışmaların insan hakları kültürünün dünya ve ülkemiz üzerinde yerleşmesinde bir mihenk taşı olacağ 1 düşüncesinin varlığını belirtmek gerekmektedir. Bu araştırma sonuçları ile de gerçekleştirilecek diğer çalışmalara güncel ve özgün bir kaynağın da sunulmuş olması ümit edilmektedir.

\section{Yazarların Katkı Oranı}

Yazarın bu makaledeki katk1 oranı \%100'dür.

\section{Çıkar Çatışması}

Araştırmada çıkar çatışması teşkil edebilecek bir durum bulunmamaktadır.

\section{Kaynaklar}

Adami, R. (2014). Toward cosmopolitan ethics in teacher education: An ontological dimension of learning human rights. Ethics and Education, 9(1), 29-38.

Akyeşilmen, N. (2014). Uluslararası insan hakları düzenlemeleri ve eğitim: Eğitime hak temelli bir bakış. Milli Eğitim Dergisi, 201, 5-14.

Birleşmiş Milletler Genel Kurulu. (1948). Insan Hakları Evrensel Beyannamesi https://www.insanveinsan.org/ adresinden 05.09.2020 tarihinde erişilmiştir.

Burridge, N. and Chodkiewicz, A. (2017). Educating teachers about human rights: building a rights based culture in Australian schools. Asia-Pacific Journal of Teacher Education, 45(5), 455468.

Cassidy, C., Brunner, R. and Webster, E. (2014). Teaching human rights? "All hell will break loose!". Education. Citizenship and Social Justice, 9(1), 19-33. 
Covell, K. , Howe, B. R. and McNeil, J. K. (2010). Implementing children's human rights education in schools. Improving Schools, 13(29), 117-132.

Council of Europe Committee of Ministers (1985). Of The Committee of Ministers To Member States on teaching and learning about human rights in schools.

https://rm.coe.int/16804c2d48 adresinden 9.4.2020 tarihinde erişilmiştir.

Creswell, J. W. (2014). Araştırma deseni: Nitel, nicel ve karma yöntem yaklaşımları. (Çev. S. B. Demir). Ankara: Eğiten Kitap.

Çiydem, E. (2014). The perceptions of prospective teachers about democracy and human rights, and the roles laid by them on social sciences course on this subject. Procedia-Social and Behavioral Sciences, 143(6), 679-686.

Dewey, J. (1990). The school and society and the child and the curriculum. Chicago \& London: The University of Chicago Press.

Emmert, S. and Eur, L. M. (2011). Education in terms of human rights. Procedia-Social and Behavioral Sciences, 12, 346-361. doi: 10.1016/j.sbspro.2011.02.044.

Ersoy, A. F., Balbağ, N. L. ve Gündoğan Bayır, Ö. (2017). İnsan hakları, yurttaşl1k ve demokrasi dersini öğretmenler ve öğrenciler nasıl algıllyor? Sakarya University Journal of Education, $7(1), 223-241$.

Gürel, D. (2016). Sınıf ve sosyal bilgiler öğretmenlerinin ilkokul 4. sınıf insan hakları, yurttaşlık ve demokrasi dersine yönelik görüşlerinin karşılıklı olarak incelenmesi. Ahi Evran Üniversitesi Kırşehir Ë̆itim Fakültesi Dergisi, 17(3), 641-660.

Gündoğdu, K. (2011). Türkiye'de öğretmen adaylarının insan hakları eğitimine yönelik tutumları. Eğitim ve Bilim, 36(162), 99-116.

Hareket, E. (2019). Temel eğitim bölümü öğrencilerinin çocuk haklarına yönelik bilişsel algıları. Başkent University Journal of Education, 6(2), 167-180.

Hareket, E. (2020). Çocuk hakları perspektifinden Türkiye'de eğitim unsurları. Başkent University Journal of Education, 7(1), 47-61.

Hareket, E. ve Yel, S. (2021). Eğitim hukukunda çocuk hakları ve eğitimi. Ankara: Anı Yayıncılık

Isenström, L. (2021). Teachers' rights-teaching mentalities - what teachers do and why. Scandinavian Journal of Educational Research, 65(1), 1-15.

Jennings, T. (2006). Human rights education standards for teachers and teacher education. Teaching Education, 17(4), 287-298.

Kwon, I., Lee, J., Cummings, C. E., Shamrova, D. P., Macomber, C. A., Milanović, E., Woodward, A. T. and Hughes, A. K. (2020). Human rights attitude and civic engagement behavior among university students. Journal of Human Rights and Social Work, 5(3), 174-184.

Leung, Y. W. and Lo, Y. L. (2012) Are liberal studies teachers ready to prepare human rights respecting students? A portrait of teachers' attitudes towards human rights. Intercultural Education, 23(4), 341-358.

Merriam, S. B. (2015). Nitel araştırma desen ve uygulama için bir rehber. (Çev. S. Turan). Ankara: Nobel Yayıncilik. 
Miles, M. B. and Huberman, A. M. (1994). An expanded sourcebook qualitative data analysis. United States of America: Sage Publications.

Özbek, R. (2017). Realization level of the citizenship and human rights education course objectives, Inonu University Journal of the Faculty of Education, 18(1), 359-371.

Patton, M. Q. (2014). Nitel araştırma ve değerlendirme yöntemleri. (Çev. M. Bütün ve S. B. Demir). Ankara: Pegem Yayıncilık.

Robson, C. (2015). Bilimsel araştırma yöntemleri. (Çev. Ş. Çınkır ve N. Demirkasımoğlu). Ankara: Anı Yayıncilik.

Robinson, C., Phillips, L. and Quennerstedt, A. (2018). Human rights education: developing a theoretical understanding of teachers' responsibilities. Educational Review, 72(2), 221-241.

Struthers, A. E. C. (2015). Human rights education: Educating about, through and for human rights. The International Journal of Human Rights, 19(1), 53-73.

Struthers, A. (2016). Human rights: a topic too controversial for mainstream education? Human Rights Law Review, 16(1), 131-162.

Toprak, E. ve Demir, S. B. (2017). İlkokul 4. sınıf "insan hakları, yurttaşlık ve demokrasi” dersinde yaşanan sorunların sınıf öğretmenleri tarafından değerlendirilmesi. Abant İzzet Baysal Üniversitesi Eğitim Fakültesi Dergisi, 17(4), 2160-2179.

Varlı, N. (2020). Kültürlerin insan hakları ihlallerine etkileri ve çözüm önerisi. İnsan ve Sosyal Bilimler Dergisi, 3(2), 622-638. 


\section{Extended Abstract}

\section{Introduction}

It is possible to describe the concept of right as a concept that human beings, as a social being, have before they are born, signifies the obligation to be protected by the authorities as a social organization and is also guaranteed by legal norms. Although there are rapid and various processes of change on a global and local scale, it is a fact that the concept of human rights is still one of the indispensable concepts of democratic societies and that education, law and policy studies on this issue continue without slowing down. At this point, human rights and freedoms, which emerge as a subject area in social life, are among the basic issues of education and educational elements, which are among the basic arguments of national and international law as well as social building. Undoubtedly, this determination raises the need for educators and teachers candidates, who are among the basic elements of educational processes, to have attained sufficient knowledge and sensitivity on human rights. In line with these views, educators, especially classroom teachers and candidates who embrace the first step in life phase, have a very important role. Based on these issues, it is necessary to ensure that human rights should be operated with real life experiences in institutions where educators who are respectful / sensitive to human rights and freedoms and who have sufficient awareness of these rights and their violations in national / international framework will be involved, Thus, it is thought that it will be possible for the social life to have a texture sensitive to human rights.

\section{Method}

702 teacher candidates who were determined by criterion sampling method participated in the research. The data of the research which was designed in accordance with the qualitative research approach, were obtained with written documents created by the participants. The qualitative data obtained were analyzed using the content analysis technique.

\section{Findings}

It is observed that the participants stated that the right to life, the right to education, children's rights, protection from discrimination, right to health and the right to bodily integrity and immunity are violated most in the world. On the other hand, it is seen that the violations in areas such as freedom of language, citizenship, freedom of the press, the right to science and art, public merit, the right to information and communication are expressed by less of a participant. Otherwise, It is seen that there is a consensus on human rights violations in our country. Among these rights violations, the right to education, sexual immunity, children's rights, the right to freedom of thought and expression, the right to be protected from violence, the right to life, protection from discrimination, fair trial and defense, freedom and security, equality and freedom of the press It seems to have been expressed by the segment. On the other hand, it is observed that the right to health, tax justice, consumer rights, housing immunity, alimony and the right to compensation are less commonly violated by far less of the participants in our country.

The determinations of the participating classroom teacher candidates regarding the causes of fundamental human rights and freedom violations have been categorized under twelve different headings. When the headings of this category are examined, it is understood that teacher candidates consider many factors in economic, social, cultural and political contexts among the basic causes of violation of human rights and freedoms.

The determinations of participating classroom teacher candidates for the prevention of fundamental human rights and freedom violations have been categorized under eleven different headings. When these category titles are examined, measures for the security of life and property, criminal practices with high deterrence, regulations to be made in education systems, rights trainings for the development of social awareness, regulations for the establishment of freedom of the press, 
policy towards an equitable and fair social structure It has been observed that their studies put forward suggestions for introducing additional protective measures for women and children, carrying out studies for the prevalence of democracy in the administration, developing social awareness on family planning and developing migration / health care policies within the framework of human rights.

\section{Conclusion, Discussion and Recommendations}

As a result of the research, it was concluded that the primary school teacher candidates have a certain level of awareness of human rights violations at international and national scale. At this point, it should be noted that there is a consensus among the teacher candidates regarding human rights violations in our country. It can be said that the reason for this finding may be that some violations of fundamental rights and freedoms are more common and more visible than in the international context.

Another result is that primary school teacher candidates have made similar determinations about human rights and freedoms, which are thought to be experienced in global and local contexts. On the basis of this result, it is possible to evaluate that the participants follow the national and international information and news flows in parallel or they consider the rights violations experienced on a global scale as the main basis of the experience in our country in terms of their power and field.

As a result of the research, primary school teachers candidates' right to education, sexual immunity, children's rights, right to freedom of thought and expression, right to protection from violence, right to life, protection from discrimination, fair trial and defense, liberty and security, equality and freedom of the press. ; In the international context, it was observed that they mostly stated that the right to life, the right to education, children's rights, protection from discrimination, the right to health and the right to bodily integrity and immunity were violated. However, it was concluded that the candidates did not have sufficient awareness of the areas of violation that could be caused by them, although they pointed out the customs, traditions and customs, social judgments and established thought patterns among the reasons for the violations of human rights and freedoms. As a matter of fact, child marriages, circumcision of girls, polygamy etc. It was considered as a striking result that the subjects such as these were not seen among the fundamental human rights violations that exist in the national and international arena by the teacher candidates.

It should be noted that these results are even more important for our country. Because the classroom teachers, who have been working mostly in rural areas for a long time since the first periods of their professional life, should have more awareness of the violations of human rights and freedoms in these regions where the elements of culture, belief, customs, traditions and social perception are more dominant in life. 